\title{
Rules and boundaries: The morality of Eve Online ${ }^{1}$
}

\author{
Óli Gneisti Sóleyjarson, Reykjavík, Iceland
}

Eve Online is a computer game designed by the Icelandic company CCP games and released in 2003. On the official website it is defined as "a massive multiplayer online roleplaying space game". ${ }^{2}$ One of the main features that sets the game apart from other massively multiplayer online games (MMOG) is the fact that it is a single game world (though a separate version is available for China), rather than a collection of worlds on different servers. The game world being whole means that the players can trust that they will encounter the same friends and enemies each time they enter the world of Eve Online. At the same time, this means that players cannot choose to log into a server that suits their particular playing style. Instead, CCP has divided the world into various sections which have, by way of in-game logic, different characteristics. This means that rather than leaving one version of the game world and logging into another, the players can move within the game world to find a place that appeals to their gaming preferences.

\section{Research objectives}

My research (conducted mostly in 2007) was not an insider's look at the game of Eve Online. I became interested in massively multiplayer online games and quickly turned my attention to this particular game. I soon came to see that participation as a research tool would be hampered by the fact that there is so much paranoia amongst the players within the game: everyone is spying on everybody else. I decided to use face-to-face interviews with both players and CCP employees as my main tool, but I also played the game to get a feel for it, read discussions on bulletin boards, and used various other ways to get information about the game and the people playing it.

\footnotetext{
${ }^{1}$ This paper, presented at the $10^{\text {th }}$ international SIEF congress in Lisbon, Portugal, 18 April 2011, is based on my MA thesis Eve Online: Leikir, sköpun og samfélög from 2009 which was published by the Icelandic Centre for Ethnology and Folklore. I would like to thank everyone who has commented on my material, Eve players who heard my presentation "Nice People - Nasty Players" at Fanfest 2011, everyone participating at the SIEF panel in Lisbon, Tómas V. Albertsson, and finally Helen F. Leslie, doctoral fellow at the University of Bergen, who also whipped my English into shape.

${ }^{2}$ Quoted from the title of the front page of the Eve Online webpage (see References).
} 
From the start, one of my main research topics was the question of morality and ethics within the game. Do people do as they please in a game that has so few rules (more about this in the next sections)? What guides their behaviour? Although some younger scholars (such as Edward Castronova ${ }^{3}$ and Jesper Juul ${ }^{4}$ ) dispute the relevance of older writings about games when dealing with computer games, especially MMOGs, I quickly came to the conclusion that even though MMOGs are a very modern form of playing, older scholarly theories about games and play are in many ways still the best methods by which to understand how people play these games.

The scholarly work that I have found the most helpful is Johan Huizinga's work Homo Ludens, where he defines play and the concept of the magic circle:

All play moves and has its being within a playground marked off beforehand eithermaterially or ideally, deliberately or as a matter of course. Just as there is no formal difference between play and ritual, so the "consecrated spot" cannot be formally distinguished from the play-ground. The arena, the card-table, the magic circle, the temple, the stage, the screen, the tennis court, the court of justice, etc., are all in form and function play-grounds, i.e. forbidden spots, isolated, hedged round, hallowed, within the ordinary world, dedicated to the performance of an act apart. $[\ldots]$ Inside the play-ground an absolute and peculiar order reigns. Here we come across another, very positive feature of play: it creates order, is order. Into an imperfect world and into the confusion of life it brings a temporary, a limited perfection. Play demands order absolute and supreme. The least deviation from it "spoils the game", robs it of its character and makes it worthless.

(Huizinga 1955, p. 10)

Roger Callois similarly argues:

The confused and intricate laws of ordinary life are replaced, in this fixed space and for this given time, by precise, arbitrary, unexceptionable rules that must be accepted as such and that govern the correct playing of the game. If the cheat violates the rules, he at least pretends to respect them: he takes advantage of the other players' loyalty to the rules. From this point of view, one must agree with the writers who have stressed the fact that the cheat's dishonesty does not destroy the game. The game is ruined by the nihilist who denounces the rules as absurd and conventional, who refuses to play because the game is meaningless.

(Caillois 2001, p. 7)

Callois also reminds us that a basic element of games is that in them it is "implied that all must play with exactly the same possibility of proving their superiority" (Caillois 2001, p. 19). With this in mind we can view the playing field.

\footnotetext{
${ }^{3}$ Castronova 2005, p. 161.

${ }^{4}$ Juul 2005, pp. 164-167.
} 


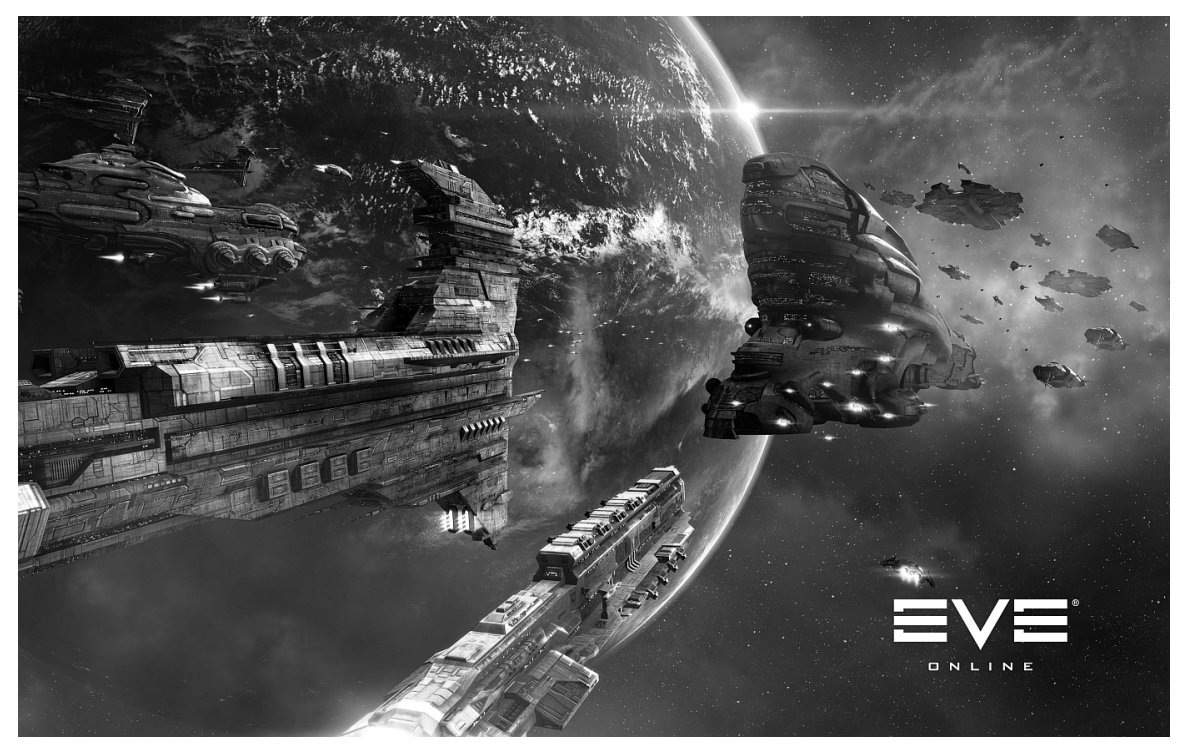

Screenshot from Eve Online

\section{The world of Eve Online}

All players start by creating a character from one of four "races" and then enter the game in a part of the world called Empire. There players can take part in a game of "player vs. environment" or "player vs. computer". In Empire, the in-game police, which are called CONCORD, keep the peace and punish those who prey on other players. When players move from the heart of Empire their safety decreases incrementally from the zone known as 1.0 , which is very safe, to 0.9 , which is a bit more dangerous, all the way down to 0.0 , which has no laws except the ones players set for themselves. In 0.0 the game is largely "player vs. player".

Each Eve Online account can have up to three game characters. This does not mean that each account can be used by three different players but rather that one player has three characters. The result of this is that players often use these extra characters, or "alts", to be of some kind of service to the main character. They can be used, for instance, to buy and sell products or materials in other parts of the Eve universe so the main character does not have to travel. They can also be used for more sinister purposes such as spying or scamming. It is also not uncommon for players to have more than one account so they can have even more characters (one of my informants had five which means he could have fifteen characters if he wanted). I was shown a setup where a player had two computers side by side. In one he had his main character, the fighter, and in the other he had an alternative character who was a miner/trader. Using this setup he could devote his time to the fighter who was supported financially by the miner/trader. 
The End user license agreement (EULA) of Eve Online makes it crystal clear that players have no right to ownership of their character or anything those characters create or own within the game. ${ }^{5}$ This protects CCP from what a former employee of the company termed "overly litigious Americans", but more importantly it protects the game itself from being subject to laws outside the game. The user agreement also states that certain behaviour is unacceptable (such as "use [of] indecent, obscene, and/or threatening or harassing language"). ${ }^{6}$

The world of Eve Online is set in the future. The inhabitants of the world, that is the players' characters, are descended from humans from Earth but have evolved so as to form different races: Amarr, Minmatar, Gallente and Caldari. A mysterious non-player character race, called Jove, also exists, or at least existed in the past and created much of the technology of the world. For standard players of Eve these races do not affect the game, but the so-called roleplayers, who like to play the role of their characters, often use the races and their backgrounds as motives for their actions. For instance, the Amaar are known for keeping people from the Minmatar as slaves, so players who are roleplaying their characters use that animosity as a basis for their actions and interactions.

Individual players can have varying goals within the game. Some play mostly because of the socializing that goes with it, some going as far as to pay the subscription costs to be able to log on the chat with their in-game friends. Other players want power and respect within the game. But in terms of in-game goals the most common denominator would most likely be that players want to advance themselves, their character and their group within the game in many different ways. They want their character to earn more as well as better skills. They also want stuff, in-game stuff. Better spaceships are sought after and better equipment for those ships. To buy this stuff they need lots and lots of the in-game currency known as ISK (a relative of the Icelandic krona, although the Eve Online version has proven to be more stable in recent years). This is a sort of non-materialistic consumerism - wanting more and more things that are no more than sequences of ones and zeroes in a computer database (which might not be so unlike our own world's current banking system).

As Danish computer game scholar Jesper Juul has pointed out, games can be placed between two polar opposites in terms of game type. On one end there are progressive games where players move through a path, for instance from one level to the next, while on the other end there are emergent games where the game designers provide an environment where the players can, in many ways, create their own game. Few games are strictly one or the other but Eve Online seems to be very close to the archetype for an emergent game. ${ }^{7}$

\footnotetext{
${ }^{5}$ For a discussion on the role of the EULA in MMOGs see Castronova 2005, pp. 156-158.

${ }^{6}$ See the End User License Agreement among the References.

${ }^{7}$ Juul 2005, pp. 67-75.
} 


\section{Me, myself and my character}

Players of Eve Online can have vastly different feelings toward their characters. On one end of the spectrum are players such as one who told me that his character was "just an extension of me. I myself have tried this pirate thing, shooting other players in lowsection but... I killed this guy who was rather new and I ended up paying him for the ship because I got such a guilty conscience" ${ }^{8}$ He could not distance his own self from the actions of the character and his game play was marked by this attitude. The polar opposite outlook could be found with a roleplayer who said: "With many people [...] it's like 'you insulted my character you insulted me' but with role playing, I enjoy acting out the character and then I log out and I'm not him any more." This does not mean that the roleplayer was a particularly nasty player but rather that he could detach himself from what happened within the game. Obviously there will be friction when players' attitudes differ so much. The second roleplayer quoted above also commented on how he and his group often subjected non-roleplayers with whom they were fighting to a barrage of in-character verbiage, which sometimes managed to scare them off. The roleplayers' dedication to playing their part was mistaken for some kind of insanity or a failure to distinguish between game and reality. I would in fact argue that, of the players I have communicated with, the roleplayers have the clearest concept of what Huizinga calls the magic circle, the line between play and non-play. This includes those roleplayers who dress up as their characters when meeting fellow players - such as at Fanfest. Their conception of reality is not at all confused, but I have seen, for instance, news reporters who have been just as mystified by that kind of behaviour as the non-roleplayers, who can become baffled when encountering the roleplayers within the game.

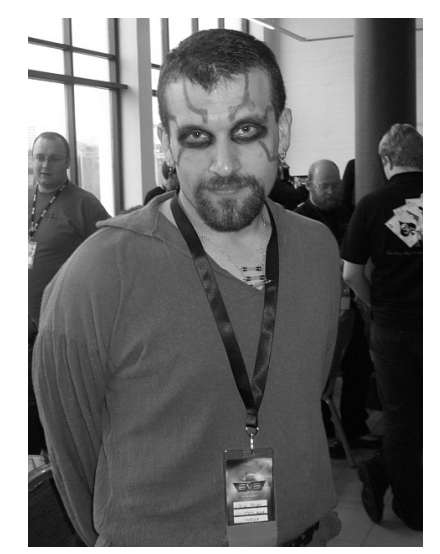

A dedicated player at Eve Online Fanfest 2007 (photo Óli Gneisti Sóleyjarson)

\footnotetext{
${ }^{8}$ Interview with Ármann on March 29, 2007.

${ }^{9}$ Interview with Jakob on June 9, 2007.
} 


\section{Groups: corps and alliances}

As in most MMOGs, players in Eve form groups to work together. The basic group unit of players in Eve is the "corp" (short for corporation). The corps often have complex hierarchies and members have very different jobs to do. There are fighters and miners - rulers and followers. One informant even claimed pride in the title of "care bear" 10 , which is often thought to be mocking toward non-fighters. The make-up of the corp has everything to do with its purpose. Some corps are simple mining companies, some are traders, while others are mercenaries or even pirates.

After the game had started, its players found that it was to their advantage to form alliances between corporations, and in time these alliances became a feature of the game. By forming alliances, the corps can extend their influence without losing the intimacy that forms within these smaller units. The foundations of the alliances are various: a mining company needs the protection of fighters to survive, for example. The fact that the game is played all over the world can also be of importance in terms of alliances and time zones, for instance it makes sense for Icelanders to join up with Russians so that while one country sleeps or works the other one can be on guard. As the game progressed so did the alliance system, with the emergence of so-called super alliances, that is, alliances between alliances.

In many ways power struggles are the most noticeable part of Eve Online. In the lawless 0.0 section of space corps, alliances and super alliances battle for dominance over solar systems and the wealth that can be harvested within them. At the same time, observers should not forget that there are many players who do not care what the powerful are doing, and simply play their little games within the game.

\section{Guiding Hand Social Club - where anything goes?}

Eve Online has the reputation of being a game where anything goes. One scholar even said that with its neoliberal atmosphere "EVE has been designed selfconsciously as a paradise for the followers of Ayn Rand". "11 A good example of the lawless nature of the game is a famous robbery performed in April 2005 by a corp called Guiding Hand Social Club. The official story of the robbery is that members of this mercenary corp were contracted by an anonymous person who wanted to wreak havoc on a certain character (and, most likely, also the player behind the character) named Mirial in the game. Guiding Hand Social Club took months to infiltrate Ubiqua Seraph, the corp in which Mirial was chief executive officer. When their spies had gained the trust of the CEO and others within the corp they executed the plan. Mirial had been persuaded to fly a really valuable spaceship with a spy from Guiding Hand Social Club at her side. The mercenaries destroyed

\footnotetext{
${ }^{10}$ Interview with Kjartan on June 4, 2007.

${ }^{11}$ Castronova 2005, p. 163. Ayn Rand (born Alisa Rosenbaum, 1905-1982) was a RussianAmerican novelist and philosopher.
} 
that ship and also the escape pod Mirial had tried to use to get away in (in Eve "podding" is seen as particularly nasty). That was not the end of it, as Members of Guiding Hand Social Club used their access to Ubiqua Seraph's properties to steal all they could. This meant that it was not only Mirial who lost her property but also every member of the group who had in some way invested time or money in it. Afterwards Guiding Hand Social Club took credit for the act. The theft was valued at 30 billion ISK. In an article in PC Gamer magazine it was claimed that the real world value of the robbery was about $\$ 16,500 .^{12}$

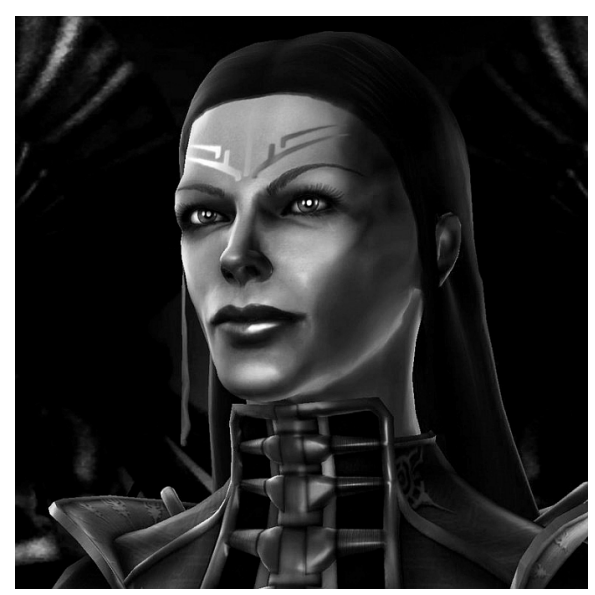

Mirial

Player response to the robbery was mixed. Some were dismayed while others applauded the act. Basically it all came down to what kind of game people want to play. One of my informants regarded it as unsportsmanlike and considered it comparable to a team member scoring a deliberate own-goal in football. On the other hand, it was also argued that this was what Eve was all about and that players should be careful about whom they trusted. When people can betray you and steal from you it adds a whole new level to the game. Reportedly, some players left Eve Online in dismay because they did not like this element of the game, but many more signed up because of it. This event helped define what the game was really about, and Eve Online thus set itself apart from other games by giving players the freedom to be nasty to each other. This in turn led to a paranoid atmosphere within the corps and alliances formed.

While doing my research I came across the player who was, and still is, the CEO of Guiding Hand Social Club. He claimed that the story of the heist was largely fictional. According to him, the members of the corp themselves wanted to get back at Mirial and had afterwards published a fictional account of what happened to lure other players and corps to engage their services. Guiding Hand

${ }^{12}$ See Murder Incorporated 2005. 
Social Club collected money from these new contracts and claimed to be working on similar operations, while in fact doing nothing. In this way, their in-game profit from the robbery was supplemented by these payments and this made them even wealthier than the original theft had made them. When I talked to the CEO, he was also - as another character - a powerful player in the politics and intrigues of Eve Online, but almost no-one knew about this. For him there was no backlash, only rewards. The strange thing was that in my opinion the anonymity that he got by using a different character to do the robbery was not what he really wanted. It seemed to me that rather than being known as a leader in the power politics of Eve Online he would have preferred the infamy that went with being associated with Guiding Hand Social Club and their mischief - both the robbery itself and also the scams that followed. That was what really made him proud, even though his actions were in effect anonymous.

Thefts such as the Guiding Hand Social Club heist can be devastating, both because of the loss of in-game property but also because of the betrayal of trust, and some players quit after being robbed. However, sometimes the traitors get second thoughts. One informant told me that some time after such a theft the thief returned to give his former corpmates ships as compensation for the money and items he had stolen from them. The player could not face playing the game with the reputation of being a thief.

\section{Ethical boundaries}

While CCP did not object to the Guiding Hand Social Club incident they do set certain boundaries for what is allowed and what is disallowed within the game. A guide in the Eve Online Wiki tries to explain the difference between scams and so called exploits in the game.

As can happen in the real world, someone in EVE may try to cheat you out of your hard-earned possessions. This may be attempted through either a scam or an exploit, and the distinction between the two is important. [...] A scam is what happens when someone takes advantage of your misplaced trust, temporary confusion or ignorance of game rules, and robs you via legal in-game means. When this occurs, there is nothing the Support Team can do for you. Although low and despicable, scams do not violate any game mechanics and can not be compensated for by the $\mathrm{GMs}^{13}$, nor can the scammers generally be punished for their actions. [...] An exploit is when someone bypasses normal game mechanics, such as by utilizing a bug in the game, allowing him to take advantage of other players without them having any means of preventing it whatsoever. When this occurs, we implore you to contact your friendly neighbourhood GM as soon as possible so that they can investigate the incident, prevent it from happening to anyone else, and possibly reimburse you for your loss. ${ }^{14}$

\footnotetext{
${ }^{13}$ A GM is a Game Master. They are CCP employees who provide customer service.

${ }^{14}$ Scams and exploits (see References).
} 
The crucial difference between a scam and an exploit is that the former can be explained via in-game logic while the latter represents a breach in the reality of the game: instead of following the settings of the game world the exploiters treat Eve Online as a computer program that can be manipulated. The line between acceptable and unacceptable behaviour by players is intrinsically linked to the line between game and not-game, the line drawn by Huizinga's magic circle.

An example of an illegal exploit in the game is one that in the early years of Eve Online was used in combat. A bug in the system caused it to show the so-called "blue screen of death" - that is, crash, when a certain module was activated. It affected not just one player but all of those around him, and in this way, a player facing hopeless odds could get away scot-free.

We can also see that the difference between what is considered moral and immoral is intrinsically linked with how the reality of the game is treated by taking a look at two kinds of traps that players set for each other. Both of them rely on getting their enemies to go after a seemingly defenceless or easy target. In one scenario, the bait tries to get the enemy to attack it near a stargate. ${ }^{15}$ On the other side there are more powerful ships waiting to come through and easily overwhelm the attacker. In the other type of trap, the enemy is overwhelmed once more powerful ships appear when their controllers suddenly log in to the game. Even though these traps seem to be alike in method, they are fundamentally different because the former adheres to the reality of the game while in the latter case players disrespect the reality of the game by manipulating it from the outside. If Eve were a real world, the first trap could work but the second trap would not. So here is a difference between a type of game play which is considered cunning and a type of play which is considered unethical.

\section{Player, rule thyself}

The fact that Eve Online is in many ways lawless does not mean that anything goes. The players do regulate themselves. The clearest example of this is in-group rules/ethics. A player cannot function as part of a group unless he or she abides by its rules. Oftentimes these rules are not laid out but are an unvoiced code of conduct that everyone has to obey. The obvious rules are the ones that concern loyalty to the group, that police themselves up to a point.

Shunning is probably the mechanism that player groups use most often to punish improper behaviour. One rather unusual corp used this method to deal with inappropriate conduct. This group was what is called "a newbie corp", intended to be used by new players who are just getting to know the game. It does not have any player-made structure as regular corps have. Some players never leave these corps and instead become something like mentors for the newbies. One member of this group was ostracised after making vulgar suggestions to a thirteen-year-old boy.

\footnotetext{
${ }^{15}$ A stargate is a space portal that enables travel from one solar system to another.
} 
One thing he purportedly said was that there was "no such thing as too young or too tight". The whole community simply stopped acknowledging the offending member's existence altogether and he was forced to leave the group. This is of course a major blow to a person who has invested time and emotion into developing relationships.

In another case, one informant described how his pirate group had hunted down a former member who had stolen something "insignificant" from them. Every time he joined a new corp that group got an ultimatum: "Kick him or go to war with us". Of course not every group can threaten other corps, but often a simple explanation of the new member's "crimes" can be enough to ensure that he is "kicked" (removed from the corporation).

Trust is also reinforced through socialising outside the game. A famous Icelandic pirate group held poker games where the stakes are in the in-game currency. The same group has a strict policy regarding who can and cannot have influence within the group. They prefer Icelanders or people living in Iceland. On the surface it seems rather xenophobic but one of the members describes the reasoning:

You can trust everybody in Iceland. They are within walking distance. ... We are building a Titan, the biggest ship in the game, and everybody who has access to it is Icelandic and we know where they live because if they steal it we will go to their house and beat them up. ${ }^{16}$

It should be noted that the tone of his voice and his demeanour implied that the "beat them up" part should not be taken literally. Simply being able to meet a person face to face helps you trust him or her. It also makes betrayal less likely since you are not able to hide behind the computer.

But in some ways players do not really think that real life should affect the game. In one instance a group of Icelanders were robbed by their corpmate, who was also Icelandic. One member decided to call the thief's parents, the thief apparently being rather young, and tell them about their son's "crime". The result was that the parents forced the thief to return all that he had stolen. The interesting thing to me was that my informant who had been robbed said "parents just don't understand these things". ${ }^{17}$ So even though he benefited from the parents' intervention, he did not think it was the right thing to do in the context of the game. It could be seen as parallel to a chess player being told off by his parents for killing all those pawns. Similarly, members of a group called Veto-Corp who had mourned the real-life death of Paul Harding/DarkElf, one of their members, by various means, did not take offence when a space station named in his honour was renamed. Their view was that the in-game rules should apply and that if they wanted the station's name to be changed back it should be done by taking it over

\footnotetext{
${ }^{16}$ Interview with Laugi on August 13, 2007.

${ }^{17}$ Ibid.
} 
by force using the reality of the game and not appealing to emotions from a real life tragedy. ${ }^{18}$

Pirates have vastly different ideas about morality when it relates to members of their own group. It is considered acceptable to attack both enemies and neutrals but within the group there might even be a spirit of share and share alike. Pirates also try to be honourable - if that makes any sense. One informant said:

If a neutral offers to pay a ransom for keeping his life and he does pay then we don't kill him. Just something you don't do. I have accidentally killed a guy who paid the ransom while I was shooting him so I refunded his money because I didn't hold up my part of the deal. You don't cheat. You're honest even if you are a little crazy. ${ }^{19}$

In the world of Eve this might of course not be considered the moral thing to do but rather an example of good "customer service". If you kill people and take their ransom then you will not get much "repeat business". The "moral character" of pirates in Eve Online might be described as like the mafia.

\section{Eve Online encounters Something Awful}

In 2006 Eve Online encountered Something Awful. One player described what happened:

There was a huge group who joined Eve a year and half ago. About 2500 or something like that and they are called GoonSwarm. They came out of the blue, first they were just noobs but they have become powerful really fast. ${ }^{20}$

The self-named "Goons" are users from the forums of Something Awful. ${ }^{21}$ By relying on sheer numbers and their pre-existing online connections they managed to become a force to be reckoned with in the Eve Online world. Many older players were annoyed by the Goons for various reasons. These new players did not have to prove themselves in the game beforehand, nor did they have to build reputations and trust. The Goons did not rely on the same strategies as the older corporations. Instead of trying to maintain a good "kill:death ratio" they sacrificed themselves using cheap ships to destroy more sophisticated (and expensive) ones and were able to gain significant advances. Their mascot was the bee and they referred to themselves as a swarm. The metaphor seems to be that while one little bee cannot really do any damage, a group of them could take down someone or something much bigger. They also mocked the older players and corporations, which they regarded as being "elitist". Instead of taking the structure of their group seriously, they elected a box of melting snowballs into a leadership position. When an opponent was hospitalized (in real life) they sent him a collection of bee-themed

\footnotetext{
${ }^{18}$ Sóleyjarson 2008.

${ }^{19}$ Interview with Pór on August 13, 2007.

${ }^{20}$ Ibid.

${ }^{21}$ www.somethingawful.com (accessed 21-2-2012).
} 
paraphernalia. Another aspect of the Goons, which seems to have followed them from the forums of Something Awful, is the use of inappropriate language by some of their members, and their use of such phrases as "faggot" and "jewing" have made the Goons unpopular with other players.

While the tactics of the GoonSwarm was frowned upon by older players, I did get the impression that there came a point where the group became a more accepted part of the game. When members of the group turned up at the 2007 Eve Online Fanfest, other players at the event soon became less hostile to them even though they kept up their mocking of the older players. It is likely that by partaking in the social event that Fanfest is, the Goons showed that they were really a part of the Eve Online community and were not simply in the game to annoy other players. Also, I think that rifts such as these in the magic circle have a tendency to heal. If the older players had not come to terms with the Goons the conflict would have had a lasting detrimental effect on the enjoyment of the game. Both sides had to compromise to continue their shared play.

\section{Illegal farming practices}

As in other similar games, Eve Online is plagued with individuals and groups, often labelled "gold farmers" (as gold is a common in-game currency), that try to make real world money from the game. ${ }^{22}$ Players who want to get an edge in the game will use real-world money to buy either in-game currency, items (such as spaceships) or even advanced characters, often because they do not want to spend time to work for these rewards themselves within the structure of the game. CCP tries to counter this behaviour, but these people evade detection by using complicated means of in-game money laundering, which can make them extremely hard to catch. While these "gold farmers" could not exist without some individuals being willing to pay for their products, players are almost universal in their condemnation of these activities. On the other hand, there does seem to be some discrepancy between how they view fellow players who buy these products and those who sell them. The players are regarded as cheaters while the sellers are thought to be a much lower type, essentially a non-player. The buyer actually cares about the game, since otherwise he would not be spending money on it. The seller is most corrupt, since he fails to care about the game as a game. He does not participate in earnest, but simply regards it as a way to make money outside of the game.

Sometimes when players get wind of "gold farmers" in the game, for instance doing some mining, they join together in groups to destroy their ships. Reportedly this does of course set the farmers back, but does not have any real long-term influence since they simply return again and again. One group of farmers did get

${ }^{22}$ For an in-depth account of the operations of these so-called gold farmers in other MMOGs see Dibbell 2006. 
fed up with being butchered so they paid in-game money to a player alliance for protection. The CEO was widely criticised for the deal. Within the game community, he defended himself by saying that there was no real evidence that pointed to this group being ISK farmers. When he talked to me he rationalised his actions by pointing the finger at CCP. The company had allowed players to buy socalled "game time cards" that are bought with real money from other players using in-game money. In his eyes this was the same as what the farmers do when they sell in-game money for real world money. His view was that it was a similar breach of the in-game reality and therefore of what Huizinga called the magic circle.

The players' dedication to maintaining a distinction between the game world and the "real" one was displayed in June 2011 when in-game riots unfurled after rumours of CCP's plans to allow players to buy spaceships in exchange for real world money. CCP commented on the issue saying that at the root of these rumours were internal speculations and not actual plans. ${ }^{23}$ However, this did not satisfy everyone, since it did not preclude the possibility of CCP going down that road some time in the future. ${ }^{24}$ In October 2011, Hilmar Veigar Pétursson CEO of CCP apologised for changes in the game that had been ill-received by the player community and said:

Unless the MMO business changes radically, our virtual goods strategy for EVE

Online will remain limited in scope and focus on vanity items, or as we said after the

CSM visit this summer: The investment of money in EVE should not give you an unfair advantage over the investment of time. ${ }^{25}$

This episode was a clear demonstration that players do want to maintain the magic circle and also to keep players' opportunities equal, as was noted by Callois.

\section{Tug of war}

Designers and the user community are in an endless tug of war about what the rules actually are. ${ }^{26}$

While we could envision Huizinga's magic circle as a line drawn with chalk where nothing outside can affect anything within and which the magician uses to protect himself from the demon he has summoned, the creators of MMOGs have a hard time keeping the "demon" in its place. Of course the sheer staggering scale of the games is a big part of it and Eve is not even one of the biggest. On the other hand, almost every time a game is played, whether it is Premier League football or a board game in the kitchen, someone argues about what the rules are or, at least, how to interpret them.

\footnotetext{
${ }^{23}$ Gylfason 2011.

${ }^{24}$ Woodhead 2011.

${ }^{25}$ Pétursson 2001.

${ }^{26}$ Castronova 2005, p. 101
} 
With this in mind when I look at what I have seen in the world of Eve Online, I am not surprised to encounter conflicts between people who have different expectations of the game. They are to be expected. What I think is remarkable is how these conflicts are resolved. Players compromise with each other or simply make room for players who have different views that can fit within the game. Some, of course, simply quit rather than adjust. For instance, it seems likely that most Eve players would never consent to a world where their fellow players can buy and sell important in-game items for real-world money. Those players who use the game to make money will always be considered false players, and those who buy play-enhancing items within the game are not only cheats but also violate the ideal of the level playing field which Callois identified as a basic element of play. Of course some inequalities are inbuilt, whether they are better running shoes in sports or a more powerful computer on which to play Eve, but these should be present from the start, unavoidable, and not added to a pre-existing game dynamic.

Play is not a perfect state where every rule is absolute and everyone agrees to it. It is rather an adaptive or self-healing process where everyone strives towards the ideal of what Huizinga termed the magic circle. This can, in fact, never be accomplished, but if the players were to stop trying to reach this perfect state, the game would surely fall apart.

\section{References}

Caillois, Roger (2001): Man, Play and Games. Chicago: University of Illinois Press. Castronova, Edward (2005): Synthetic Worlds: The Business Culture of Online Games. Chicago: University of Chicago Press.

Dibbell, Julian (2006): Play Money: Or, How I Quit My Day job and Made Millions Trading Virtual Loot. New York: Basic Books, 2006.

End User License Agreement. EVE Online. Url: http://www.eveonline.com/pnp/eula.asp (accessed 21-2-2012)

EVE Online. Url: http://www.eveonline.com/ (accessed 21-2-2012)

Gylfason, Arnar Hrafn (2011): Fearless, virtual goods, and rage. In: Dev Blog, June 24, 2011. Url: http://www.eveonline.com/devblog.asp?a=blog\&bid=932 (accessed 21-2-2012)

Huizinga, Johan (1955): Homo Ludens: A Study of the Play Element in Culture. Boston, MA: Beacon.

Juul, Jesper (2005): Half-real: Video Games between Real Rules and Fictional Worlds. Cambridge, MA: MIT Press.

Murder Incorporated. PC Gamer Magazine, September 2005. Url: http://www.computerandvideogames.com/article.php?id=180867 (accessed 21-2-2012)

Pétursson, Hilmar Veigar (2011): A letter to the followers of Eve. Dev Blog, October 5, 2011. Url: http://www.eveonline.com/devblog.asp?a=blog\&nbid=2672 (accessed 21-2-2012)

Scams and exploits. EVElopedia - The EVE Online Wiki. Url: http://wiki.eveonline.com/en/wiki/Scam (accessed 21-2-2012). 
Sóleyjarson, Óli Gneisti (2008): Missing man: death in an online world. Béascna 4, pp. 112-124.

Sóleyjarson, Óli Gneisti (2009): Eve Online: Leikir, sköpun og samfélög. Hólmavík: Icelandic Centre for Ethnology and Folklore.

Woodhead, Robert (2011): Black Friday. Confessions of a Starship Politician, June 24, 2011. Url: http://treborofthecsm.blogspot.com/2011/06/black-friday.html (accessed 21-2-2012). 